\title{
The Impact of Social Media Characteristics on Customer Purchasing Process: A Field Study at Jordanian Universities Students in Amman
}

\author{
Ali Hussein Aldhaym
}

\author{
Mohammed Atwah Al-Ma'aitah \\ Al-Balqa Applied University
}

\begin{abstract}
This study aimed to investigate the impact of the social media characteristics on the customer purchasing process. The study population included the Jordanian universities students in Amman. A 5 Likert scale questionnaire was developed and managed electronically to collect the data for analysis. A convenience samples consisted of (406) students was used. The statistical analysis method was used and conducted by SPSS software. The main finding revealed that there is a statistical significant impact of social media characteristics on customer purchasing process. This study came with several recommendations; Companies who use social media should focus on increase conversation with and among customers through being more responsive to customers' queries and focus on trigger customers to establish conversations about their products and services. Companies should be super honest in the information that provided about products and services and make sure that information consistent with the information provided by other customers which contribute to increase customer trust the company. Finally, Companies should utilize the feature of social sites to improve customer confidence in e-procurement.
\end{abstract}

\section{Keywords}

Social Media Characteristics, Customer Purchasing Process, Universities Students.

\section{INTRODUCTION}

Social media has exponentially changed the communication and sharing information and interest among people where that allow them to evaluate and make recommendations as well as provide impressions about product and services for future purchaser [1]. Moreover, it became one of the biggest sources of information, and it plays a vital role in all aspects of our life. Indeed, any attempt to searching for information, the social media will be our first choice especially if those information regard to product or services, where, when we start our purchasing journey, we begin with collecting information about the product that we intend to purchase and compare the available alternatives through asking the preowners/users of this product through social media. Indeed, one Post in Facebook adequate to collect the required feedbacks and imprecations about the product, and watching a couple of videos in YouTube are enough to gain detailed information that enables you to choose the most appropriate of the available alternatives with the lowest price.

\section{THEORETICAL BACKGROUND}

\subsection{Social media characteristics}

Social media is a broad term, where have been provided many definitions by scholars for social media, such as MerriamWebster dictionary, it as form of electronic communication that enable online communication (through instead messages or voice and video call) and sharing/exchanging of ideas, information, or any other contents between people or institutions. [2] Describe social media as applications that allow people to communicate through creating accounts that contain personal information and other contents such as photos and videos, and interact with other people through messages and access to other people (friends, colleagues, or strangers) profiles. Nowadays there are a hundreds of social media websites, the most popular is Facebook with more than billion and quarter user, and these sites have a high popularity especially among younger people. Moreover, the using of Social media had extended to business, where companies used social media as an instrument for marketing or to support the creation of brand communities [3]. In addition social media platforms are share most or all of the same attribute and characteristics[4], where those characteristics have identified by a number of researchers such as [5] who listed five characteristics that underline all the functions and operation of the social media sites : participation, openness, conversation, community, and connectedness. [4] argued that these characteristics are the fundamental dimensions of social media.

In the following we will discuss these characteristics:

Participation: this concept refers to providing the opportunity for the interested people to share and interact with other partners, which encourage people to contribute and provide feedback for each other [5]. Moreover, Participatory is one of the most distinctive characteristics of social media because it allows parties to engage in an interaction[4], furthermore, it blurs the line between media and audience [5].

Openness: this characteristic reflects the degree to which social media sites are free and open to feedback and allow users to participate and share information on their own experiences and opinions through the use of comments and voting; moreover, there is no any barriers or constraints neither to access nor making use of content [5]. [6] argued that web is "near-frictionless media channel along which anything can flow" while the most channels have a barriers and limitations to the flow and exchange of knowledge and information; however, social media sites both in applications and technological transferability contains limited flow barriers which lead to easily flow of information among sources and users([6],[4]).

Conversation: whereas traditional media provide one way communication or transmissions of information like TV, newspaper, and radio, social media enable two way conversations [5]. Moreover, traditional media channels provide a linear communication mechanism the social media 
provides a non-linear communication environment [7]. However, the degree of conversationality based on the type of social media channel and the core utilities and structures inherent in these social media for instant, Facebook provides a numerous Conversation mechanisms to enable communication among users, YouTube offers less or limited communication component comparatively to Facebook [8].

Community: this concept explains how social media enables quick and effective communication which allows communities to share common interested such as favorite TV shows and political issues and to communicate with the people whom they want to be associated with [5]. Moreover, [4] asserted that "social media provides an effective means of developing communities, but its core utility is in linking individuals and organizations with others that share a certain commonality, as determined by their temporal needs and interests at the time of interaction.

Connectedness: communication technologies allow people to maintain their personal ties even if there is no face to face communication [9]. Through allowing people to move from site to site or to a numerous resource and people by using Web links and offers connectedness to its users [5]. [10] defined Social connectedness "interpersonal, community, and general social ties". which is considering as a type of relational scheme. In this sense, Low connectedness leads people to psychologically experience that they are distant from others and outsiders; however, high connectedness makes people feel amiable and close to others as well as allow them to engage with social groups. Moreover, social media allow people to tie to the outside world and to easily expand their experience [11]

\subsection{Customer Purchasing Process}

Scholars have examined human behavior, where they did their best in order to discover and develop patterns and habits of human to facilitate understanding and interpreting the human behavior. One of the most important elements that leads to success or failure of any business is understand customer's behavior, which allows companies to eliminate or decrease the influence of the factors that affect customer while purchasing and try to leverage these factors to increase the control in this behavior. After decades of examining and investigating of customer behavior, scholars illustrated the process that customer mostly go through while purchasing and named it with a number of names such as, customer purchasing process ,customer buying decision process, customer purchasing decision process.

The prior researchers divided this process into five stages that customers go through before, during, and after the commercial transaction in order to purchase, whether it pre-determined or undetermined product or services [12]. The customers in this process go through five stages while purchasing, these stages are as the following: need recognition, information search, evaluation of alternative, purchase, post purchase evaluation ([13],[12]). However, sometimes customer doesn't go through all the stages, he could skip one or two of them, for example if you were thirsty and your favorite drink is Pepsi you will skip the stages of information search and evaluating alternative, and go directly from need recognition to purchase decision. Moreover, through these stages the customer determine what, and the quantity to buy, as well as it helps to understand any purchasing involving some detail considerations [12]. In the following we will discuss each stage in the customer purchasing process:

\section{Need Recognition}

The first stage of the purchasing process is need recognition; at this stage the customer realizes that he has a problem or need. Moreover, there are two sources or triggers that make the customer realize that he has a need or problem, internal and external. Internal source, for instance, I am hungry I need to eat a sandwich, or I need clothes, And external source such as advertisement ([12], [14]). [15] Described the external triggers of customer need 'the buyers' decisions are affected by numerous stimuli from their environment; the commercial environment consists of the marketing activities of various firms by which they attempt to communicate the buyers".

\section{Information Search}

The stage of information search starts after the customer realizes that he has a problem or need. However, this stage could be skipped if the customer knows what product that optimal to meet his need according to his attitude, and makes the buying decision without going through information search and evaluation of alternative. [12] otherwise, the process of searching for information starts, [12] and [14] categorized information sources into four types that could provide customers with information would make them able to make the decision; personal such as family and friends, commercial like sales persons and advertisement, public such as newspaper, and Experiential as using the product. However, [14] argued that, the most affective and the least amount of information obtained by customer from the personal and public sources, while the commercial advertisements, formed the largest source of information about the product. Moreover, the word of mouth is the most trustworthy source of information and the customers are relying on it in order to make the purchasing decision.

\section{Evaluation of Alternative}

In this stage the customer chooses among the available products in the market [12] Moreover, he described the most important factor in this stage" The important factor which influences the extent of evaluation is whether the customer feels involved in the purchasing of the product. Involvement here means the degree of perceived relevance and personal importance that go with the choice of a particular brand". The stage of evaluation of alternative stage closely related and depend on the stage of information search because the customer store the obtained information in each brand or product and then rank them according to his/her preferences in order to make the decision what to purchase [15].

\section{Purchase Decision}

[12] categorized this stage to three sub stages, the first one depends on the stages of information search and evaluation alternatives because in some cases the customer form preferences for some products [16], in which customer selects the preferred product according to his finding in the last two stages. The second sub stage the customer makes the decision to purchase, in the third sub stage the customer implements the decision by paying and acquiring for product. However, the purchase stage affected by number of factors such as cash flow and the availability of chosen product [16]. Moreover, the perceived risk could enforce the customer to avoid or postpone the purchase decision because the customer perceive a number of risk types in purchase decision such as functional, financial, and Physical risks ([17], [14]).

\section{Post-Purchase Evaluation}

At this stage the customer compares between his expectations about the product and what he actually find [18] if the customer's expectations match or exceed the perceived 
performance of the product the customer will be satisfied, and dissatisfied if it is not [16.] [19] argue that "The postpurchase period consists of product ownership and usage which provide contexts of satisfaction appraisal, sellerdirected complaints, word-of-mouth transmissions and repurchase planning", where the customer will use his experience positively in his evaluation alternative stage in future purchasing if his expectations match or exceed what he actually find, which will lead to make him willing to repurchase again and provide positive feedback in others information search and evaluation alternative stages.

\section{RESEARCH MODEL AND HYPOTHESES}

Depending on the reviews of the related literature and previous discussion, the research model is proposed, as shown in (Fig1):

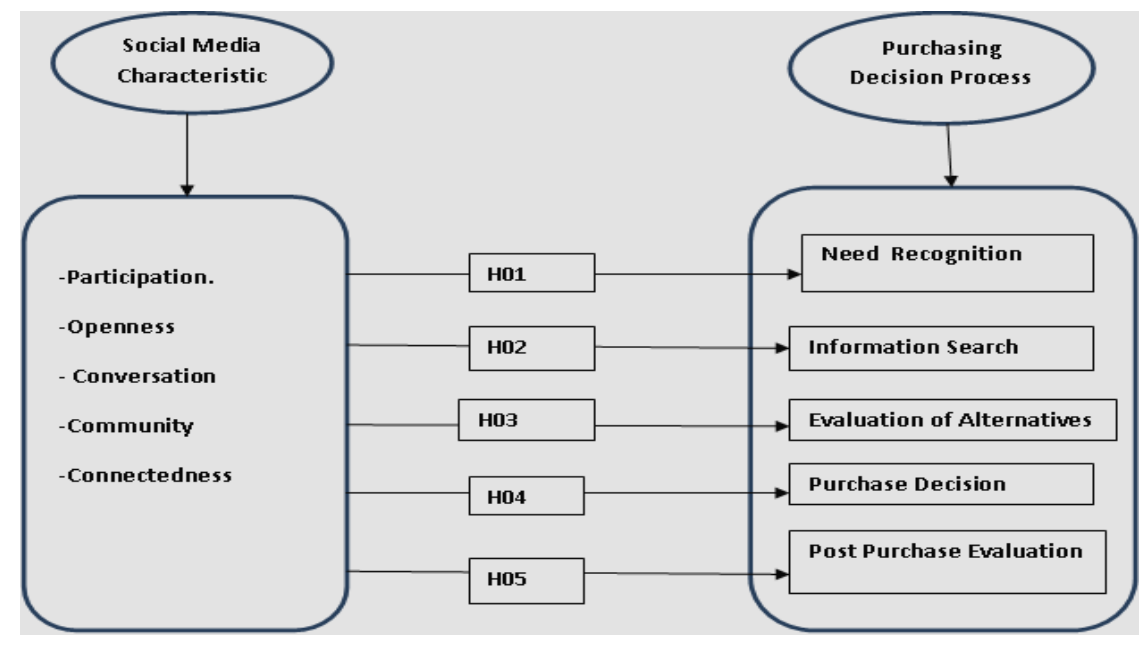

Fig 1: Research Model

In the following we will discuss more precisely how social media affect each stage in the purchasing process, followed by the related hypotheses.

\section{Need Recognition}

As we illustrated before, need recognition stage starts when customer realizes that he/she has unfulfilled need that triggered by internal or external stimuli. Indeed, social media can play a significant role in trigger customer unfulfilled need through advertisements or discussion with friends, for example, when Facebook user cliché "like" button or write "comment" in advertisement for product or service all his friends on facebook will see this "like" or "comment". In addition, Youtube and Twitter can make the same contribution for need recognition stage because they act in the same way which leads to trigger new need for other people [20].

H01: There is no significant impact at $(\alpha \leq 0.05)$ of social media characteristic (Participation, Openness, Conversation, Community, Connectedness) on need recognition.

\section{Information Search Stage}

When need recognition stage ends, the customer starts exploring and collecting information about the product or service that can fulfill their unfulfilled need. Social media forms a rich source of information, where customer can ask "friends" or fined the required information in brands pages they "like" in facebook of "follow" in twitter [21].

[22] argued that information search stage contains two types of search internal and external, in the internal search the customer depends on his/her own experience and knowledge, where in the external search the customer relies on their friends, family, and even a unknown people experience and knowledge, where social media can form an effective instrument for reaching those knowledge, experience, and information. Moreover, there is a number of factors that make customer conducting an intensive search for information about certain product or service such as, the customer buy this product or service for the first time, or it's an expensive, where social media platforms play an effective role in this case where it allows users to gain valuable information about product and service they are intend to buy . In addition, social media provide two-way communication between customer and companies and it enables consumers to engage dialogues with companies. However, customers trust in other customers more than the companies, and consider the information provided by other customer more trustful than that provided by companies [20].

H02: There is no significant impact at $(\alpha \leq 0.05)$ of social media characteristic (Participation, Openness, Conversation, Community, Connectedness) on information search.

\section{Evaluation of Alternatives}

According to [20] evaluation of alternatives stage, has the greatest affection from peers experience, where in this stage customer starts evaluate and labile products or services through seeking to compare among the alternatives that available to them in order to make the choice that seems more suit to their unfulfilled need. Thus, social media enables new customers to discussion with former or current customer which allows them to acquire valuable information. [23] stated that, the information gained from family or trusted friends about their own experience are highly influential. Where, social media allows customer to explore a massive amount of opinions and reviews from family, friends, and strangers, which makes them able to compare between possible alternatives [20].

H03: There is no significant impact at $(\alpha \leq 0.05)$ of social media characteristic (Participation, Openness, Conversation, Community, Connectedness) on evaluation of alternatives Purchase Decision Stage 
According tO [22] customer in this stage stops all the activities that involve of searching or evaluation of information, and move toward making the decision whether to purchase or not, where the customer's decision depends on two factors, the first one is the results he/she gained from information search and evaluation of alternative stages that relied on opinions, reviews, and recommendations in social media. The second factor is the motivation from other customers

H04: There is no significant impact at $(\alpha \leq 0.05)$ of social media characteristic (Participation, Openness, Conversation, Community, Connectedness) on Purchase

\section{Post-Purchase Evaluation}

The last stage in the customer purchasing process, is the stage where the customer evaluate the outcome of the all previous stages[21]. The customer compares between his expectations about the product and what he actually find [18]. According to [20] it's the most important stage to the customer because it will affect his future purchase trends and other customer where the customer in all previous stages the customer being a receiver of the information but in post purchase evaluation the customer become a provider of other customer, where social media an effective instrument that allows customer to share their own experience and provide reviews and recommendations with peers.

H05: There is no significant impact at $(\alpha \leq 0.05)$ of social media characteristic (Participation, Openness, Conversation, Community, Connectedness) on post purchase evaluation

\section{RESEARCH METHODOLOGY}

The researcher adopts analytical descriptive methodology approach in conducting this research to investigate the Impact of Social Media Characteristics on Customer Purchasing Process.

\subsection{Population and Sample}

The population of this research consists of Jordanian Universities Students in Amman, where the researcher used convenience sample in order to conduce this research. The researcher had developed an online survey and distribute it through Facebook universities groups provided that responders are students of Bachelor, Master, or Ph.D. Additionally (406) questionnaires have been reserved.

\subsection{Instrument Validity}

The questionnaire has been judged by seven academic whose have a sufficient experience and knowledge in order to show their opinion in terms of the alignment of the survey items with study variables.

\subsection{Instrument Reliability}

According to table (1) it's illustrated that result of Cronbach Alpha Coefficient was greater than (0.70) for all constructs, so the value of Cronbach Alpha Coefficient is accepted and highly reliable and we can approve that the questionnaire items are consistent [24].
Table (1) Reliability Test (Cronbach Alpha Coefficient)

\begin{tabular}{|c|c|c|c|}
\hline The Variable & The Dimension & $\begin{array}{c}\text { Cronbach } \\
\text { Alpha }\end{array}$ & $\begin{array}{l}\text { No of } \\
\text { items }\end{array}$ \\
\hline \multirow{5}{*}{$\begin{array}{l}\text { Social media } \\
\text { characteristics }\end{array}$} & Participation & $\% 71.23$ & 3 \\
\hline & Openness & $\% 76.05$ & 5 \\
\hline & Conversation & $\% 74.13$ & 5 \\
\hline & Community & $\% 78.93$ & 4 \\
\hline & Connectedness & $\% 66.63$ & 4 \\
\hline \multirow{5}{*}{$\begin{array}{l}\text { Customer } \\
\text { purchasing } \\
\text { process }\end{array}$} & Need recognition & $\% 84.19$ & 4 \\
\hline & Information search & $\% 78.59$ & 4 \\
\hline & $\begin{array}{l}\text { Evaluation of } \\
\text { alternatives }\end{array}$ & $\% 79.14$ & 4 \\
\hline & Purchase Decision & $\% 83.11$ & 3 \\
\hline & $\begin{array}{l}\text { Post- Purchase } \\
\text { Evaluation }\end{array}$ & $\% 83.49$ & 3 \\
\hline
\end{tabular}

\subsection{Multicollinearity}

Table (2) indicates that the accepted Tolerance-value for the variables is that less than 1 and greater than 0.01 , as were values of VIF less than 5 , where its considered as clear indicators to not the existence of a strong linkage among the independent variables, where this indicates acceptance of values and its suitable for conducting linear regression analysis and testing the hypotheses (Hair etal 201)

Table (2) VIF and Tolerance

\begin{tabular}{|c|c|c|}
\hline $\begin{array}{c}\text { The independent } \\
\text { variables }\end{array}$ & VIF & Tolerance \\
\hline Participation & 1.560 & 0.641 \\
\hline Openness & 1.305 & 0.767 \\
\hline Conversation & 2.274 & 0.440 \\
\hline Community & 1.879 & 0.532 \\
\hline Connectedness & 1.784 & 0.560 \\
\hline
\end{tabular}

\section{HYPOTHESES TESTING}

First hypothesis:" There is no significant impact of social media characteristic (Participation, Openness, Conversation, Community, and Connectedness) on Need recognition, at $(\alpha \leq 0.05) "$.

Multiple linear regression was used to test the hypothesis, and the results are shown in Table (3). 
Table (3) the results of testing first hypothesis

\begin{tabular}{|c|c|c|c|c|c|c|c|c|c|}
\hline \multirow{2}{*}{$\begin{array}{l}\text { Dependent } \\
\text { Variables }\end{array}$} & \multicolumn{2}{|c|}{ Model Summary } & \multicolumn{2}{|c|}{ ANOVA } & \multicolumn{5}{|c|}{ Coefficient } \\
\hline & $\mathrm{R}$ & $\mathrm{R}^{2}$ & $\mathrm{~F}$ & Sig & Dimension & St Error & Beta & $\mathrm{T}$ & Sig \\
\hline \multirow{5}{*}{$\begin{array}{l}\text { Need } \\
\text { recognition }\end{array}$} & \multirow{5}{*}{0.60} & \multirow{5}{*}{0.366} & \multirow{5}{*}{45.70} & \multirow{5}{*}{${ }^{*} 0.00$} & Participation & 0.04 & 0.169 & 3.38 & *0.01 \\
\hline & & & & & Openness & 0.05 & 0.053 & 1.16 & 0.246 \\
\hline & & & & & Conversation & 0.06 & 0.137 & 2.27 & *0.023 \\
\hline & & & & & Community & 0.05 & 0.291 & 5.31 & $* 0.00$ \\
\hline & & & & & Connectedness & 0.06 & 0.124 & 2.32 & *0.021 \\
\hline
\end{tabular}

Table(3) indicates that there is statistical significant impact of social media characteristics (Participation, Openness, Conversation, Community, and Connectedness) on Need recognition through $F$ value $(45.703)$ at $(\alpha \leq 0.05)$. and the value of $R^{2}(0.366)$ indicates that, social media characteristics explained (\%36.6)of the variation in Need Recognition. And The $\mathrm{R}$ value is (\%60.5) that means there is a positive relationship between social media characteristics and Need recognition. The results of partial analysis for this hypothesis shows that the dimension (Community) achieved the first rank in the contribution of direct impact in the group on Need recognition where shown through $(\beta)$ value $(0.291)$, and $(\mathrm{T})$ value (5.310), at $(\alpha \leq 0.05)$. While the dimension (Participation) achieved the second rank in the contribution of direct impact in the group on Need recognition where shown through $(\beta)$ value (0.169), and (T) value (3.382), at $(\alpha \leq 0.05)$. And the dimension (Connectedness) achieved the third rank in the contribution of direct impact in the group on Need recognition where shown through $(\beta)$ value $(0.124)$, and $(\mathrm{T})$ value $(2.320)$, at $(\alpha \leq 0.05)$. And the dimension (Conversation) achieved the fourth rank in the contribution of direct impact in the group on
Need recognition where shown through $(\beta)$ value $(0.137)$, and (T) value (2.275), at $(\alpha \leq 0.05)$.

However, the dimension (Openness) did not achieve contribution of direct impact in the group on Need recognition where shown through $(\beta)$ value and $(\mathrm{T})$ value that shown in table (3) at $(\alpha \leq 0.05)$.

According to the previous we reject the null hypothesis and accept the alternative hypothesis where it was proved that there is significance statistical impact at $(\alpha \leq 0.05)$ of social media characteristics on Need recognition.

Second hypothesis:" There is no significant impact of social media characteristic (Participation, Openness, Conversation, Community, and Connectedness) on Information search, at $(\alpha \leq 0.05)$ ".

Multiple linear regressions was used to test the hypothesis, and the results are shown in

Table (4).

Table (4) the results of testing second hypothesis

\begin{tabular}{|c|c|c|c|c|c|c|c|c|c|}
\hline \multirow{2}{*}{$\begin{array}{l}\text { Dependent } \\
\text { Variables }\end{array}$} & \multicolumn{2}{|c|}{ Model Summary } & \multicolumn{2}{|c|}{ ANOVA } & \multicolumn{5}{|c|}{ Coefficient } \\
\hline & $\mathrm{R}$ & $\mathrm{R}^{2}$ & F & Sig & Dimension & St Error & Beta & $\mathrm{T}$ & Sig \\
\hline \multirow{5}{*}{$\begin{array}{l}\text { Information } \\
\text { search }\end{array}$} & \multirow{5}{*}{0.577} & \multirow{5}{*}{0.366} & \multirow{5}{*}{39.338} & \multirow{5}{*}{$* 0.00$} & Participation & 0.045 & 0.101 & 1.974 & *0.049 \\
\hline & & & & & Openness & 0.052 & 0.148 & 3.141 & $* 0.002$ \\
\hline & & & & & Conversation & 0.062 & 0.200 & 3.219 & $* 0.001$ \\
\hline & & & & & Community & 0.049 & 0.266 & 4.719 & ${ }^{*} 0.00$ \\
\hline & & & & & Connectedness & 0.062 & 0.037 & 0.665 & 0.506 \\
\hline
\end{tabular}

Table(4) indicates that there is statistical significant impact of social media characteristics (Participation, Openness, Conversation, Community, and Connectedness) on Information search through $F$ value $(39.338)$ at $(\alpha \leq 0.05)$. and the value of $R^{2}(0.332)$ indicates that, social media characteristics explained (\%33.2)of the variation in Information Search. And The $\mathrm{R}$ value is (\%57.7) that means there is a positive relationship between social media characteristics and Information search. 
The results of the partial analysis for this hypothesis shows that the dimension (Community) achieved the first rank in the contribution of direct impact in the group on Information search where shown through $(\beta)$ value $(0.226)$, and $(\mathrm{T})$ value (4.719), at $(\alpha \leq 0.05)$. While the dimension (Conversation) achieved the second rank in the contribution of direct impact in the group on Information search where shown through $(\beta)$ value (0.200), and (T) value (3.219), at $(\alpha \leq 0.05)$. And the dimension (Openness) achieved the third rank in the contribution of direct impact in the group on Information search where shown through $(\beta)$ value $(0.148)$, and $(T)$ value (3.141), at $(\alpha \leq 0.05)$. And the dimension (Participation) achieved the fourth rank in the contribution of direct impact in the group on Information search where shown through $(\beta)$ value $(0.101)$, and $(T)$ value (1.974), at $(\alpha \leq 0.05)$.

However, the dimension (Connectedness) did not achieve contribution of direct impact in the group on Information search where shown through $(\beta)$ value and $(T)$ value that shown in table (4) at $(\alpha \leq 0.05)$.

According to the previous we reject the null hypothesis and accept the alternative hypothesis where it was proved that there is significance statistical impact at $(\alpha \leq 0.05)$ of social media characteristics on Information search.

Third hypothesis: "There is no significant impact of social media characteristic (Participation, Openness, Conversation, Community, and Connectedness) on Evaluation of alternatives, at $(\alpha \leq 0.05)$ ".

Mmultiple linear regression was used to test the hypothesis, and the results are shown in Table (5).

Table (5) the results of testing third hypothesis

\begin{tabular}{|c|c|c|c|c|c|c|c|c|c|}
\hline \multirow{2}{*}{$\begin{array}{l}\text { Dependent } \\
\text { Variables }\end{array}$} & \multicolumn{2}{|c|}{ Model Summary } & \multicolumn{2}{|c|}{ ANOVA } & \multicolumn{5}{|c|}{ Coefficient } \\
\hline & $\mathrm{R}$ & $\mathrm{R}^{2}$ & $\mathrm{~F}$ & Sig & Dimension & St Error & Beta & $\mathrm{T}$ & Sig \\
\hline \multirow{5}{*}{$\begin{array}{l}\text { Evaluation of } \\
\text { alternatives }\end{array}$} & \multirow{5}{*}{0.580} & \multirow{5}{*}{0.336} & \multirow{5}{*}{40.058} & \multirow{5}{*}{${ }^{*} 0.00$} & Participation & 0.045 & 0.105 & 2.051 & $* 0.041$ \\
\hline & & & & & Openness & 0.052 & 0.149 & 2.638 & $* 0.009$ \\
\hline & & & & & Conversation & 0.062 & 0.163 & 3.177 & $* 0.002$ \\
\hline & & & & & Community & 0.049 & 0.298 & 5.305 & $* 0.00$ \\
\hline & & & & & Connectedness & 0.062 & 0.042 & 0.768 & 0.443 \\
\hline
\end{tabular}

Table(5) indicates that there is statistical significant impact of social media characteristics (Participation, Openness, Conversation, Community, and Connectedness) on Evaluation of alternatives through $F$ value $(40.058)$ at $(\alpha \leq 0.05)$.and the value of $R^{2}(0.336)$ indicates that, social media characteristics explained (\%33.6)of the variation in Evaluation of Alternatives. and The $\mathrm{R}$ value is (\%58) that means there is a positive relationship between social media characteristics and Evaluation of alternatives. The results of the partial analysis for this hypothesis shows that the dimension (Community) achieved the first rank in the contribution of direct impact in the group on Evaluation of alternatives where shown through ( $\beta$ ) value (0.298), and ( $T)$ value (5.305), at $(\alpha \leq 0.05)$. While the dimension (Conversation) achieved the second rank in the contribution of direct impact in the group on Evaluation of alternatives where shown through $(\beta)$ value $(0.163)$, and $(\mathrm{T})$ value (3.177), at $(\alpha \leq 0.05)$. And the dimension (Openness) achieved the third rank in the contribution of direct impact in the group on Evaluation of alternatives where shown through $(\beta)$ value $(0.149)$, and $(T)$ value $(2.638)$, at $(\alpha \leq 0.05)$. And the dimension (Participation) achieved the fourth rank in the contribution of direct impact in the group on Evaluation of alternatives where shown through $(\beta)$ value $(0.105)$, and $(\mathrm{T})$ value (2.051), at $(\alpha \leq 0.05)$.

However, the dimension (Connectedness) did not achieve contribution of direct impact in the group on Evaluation of alternatives where shown through $(\beta)$ value and $(\mathrm{T})$ value that shown in table (5) at $(\alpha \leq 0.05)$.

According to the previous we reject the null hypothesis and accept the alternative hypothesis where it was proved that there is significance statistical impact at $(\alpha \leq 0.05)$ of social media characteristics on Evaluation of alternatives.

Fourth hypothesis:"There is no significant impact of social media characteristic (Participation, Openness, Conversation, Community, and Connectedness) on Purchase Decision, at $(\alpha \leq 0.05)$ ".

Multiple linear regressions was used to test the hypothesis, and the results are shown in

Table (6). 
Table (6) the results of testing fourth hypothesis

\begin{tabular}{|c|c|c|c|c|c|c|c|c|c|}
\hline \multirow{2}{*}{$\begin{array}{l}\text { Dependent } \\
\text { Variables }\end{array}$} & \multicolumn{2}{|c|}{ Model Summary } & \multicolumn{2}{|c|}{ ANOVA } & \multicolumn{5}{|c|}{ Coefficient } \\
\hline & $\mathrm{R}$ & $\mathrm{R}^{2}$ & $\mathrm{~F}$ & Sig & Dimension & St Error & Beta & $\mathrm{T}$ & Sig \\
\hline \multirow{5}{*}{$\begin{array}{l}\text { Purchase } \\
\text { Decision }\end{array}$} & \multirow{5}{*}{0.514} & \multirow{5}{*}{0.265} & \multirow{5}{*}{28.439} & \multirow{5}{*}{ *0.00 } & Participation & 0.055 & 0.023 & 2.051 & 0.664 \\
\hline & & & & & Openness & 0.063 & 0.080 & 2.638 & 0.104 \\
\hline & & & & & Conversation & 0.075 & 0.185 & 3.177 & *0.005 \\
\hline & & & & & Community & 0.060 & 0.317 & 5.305 & $* 0.00$ \\
\hline & & & & & Connectedness & 0.075 & 0.020 & 0.768 & 0.724 \\
\hline
\end{tabular}

Table(6) indicates that there is statistical significant impact of social media characteristics (Participation, Openness, Conversation, Community, and Connectedness) on Purchase Decision through $F$ value $(28.439)$ at $(\alpha \leq 0.05)$. and the value of $\mathrm{R}^{2}(0.265)$ indicates that, social media characteristics explained (\%26.5) of the variation in Purchase Decision. And The $\mathrm{R}$ value is (\%51.4) that means there is a positive relationship between social media characteristics and Purchase Decision. The results of the partial analysis for this hypothesis shows that the dimension (Community) achieved the first rank in the contribution of direct impact in the group on Purchase Decision where shown through $(\beta)$ value (0.317), and $(\mathrm{T})$ value $(5.353)$, at $(\alpha \leq 0.05)$. While the dimension (Conversation) achieve the second rank in the contribution of direct impact in the group on Purchase Decision where shown through $(\beta)$ value $(0.185)$, and $(\mathrm{T})$ value $(2.841)$, at $(\alpha \leq 0.05)$
.However, the other dimensions did not achieve contribution on the impact in the group on Purchase Decision where shown through $(\beta)$ value and $(\mathrm{T})$ value that shown in table (6) at $(\alpha \leq 0.05)$. According to the previous we reject the null hypothesis and accept the alternative hypothesis Where it was proved that there is significance statistical impact at $(\alpha \leq 0.05)$ of social media characteristics on Purchase Decision.

Fifth hypothesis:"There is no significant impact of social media characteristic (Participation, Openness, Conversation, Community, and Connectedness) on Post purchase evaluation, at $(\alpha \leq 0.05)$ ".

While the multiple linear regression was used to test the hypothesis, and the results are shown in table (7)

Table (7) the results of testing fifth hypothesis

\begin{tabular}{|c|c|c|c|c|c|c|c|c|c|}
\hline \multirow{2}{*}{$\begin{array}{l}\text { Dependent } \\
\text { Variables }\end{array}$} & \multicolumn{2}{|c|}{ Model Summary } & \multicolumn{2}{|c|}{ ANOVA } & \multicolumn{5}{|c|}{ Coefficient } \\
\hline & $\mathrm{R}$ & $\mathrm{R}^{2}$ & $\mathrm{~F}$ & Sig & Dimension & St Error & Beta & $\mathrm{T}$ & Sig \\
\hline \multirow[t]{5}{*}{$\begin{array}{l}\text { Post purchase } \\
\text { evaluation }\end{array}$} & \multirow{5}{*}{0.681} & \multirow{5}{*}{0.464} & \multirow{5}{*}{68.412} & \multirow{5}{*}{$* 0.00$} & Participation & 0.052 & 0.394 & 8.558 & $* 0.00$ \\
\hline & & & & & Openness & 0.059 & 0.016 & 0.371 & 0.711 \\
\hline & & & & & Conversation & 0.071 & 0.248 & 4.460 & $* 0.00$ \\
\hline & & & & & Community & 0.056 & 0.109 & 2.151 & *0.032 \\
\hline & & & & & Connectedness & 0.071 & 0.061 & 1.234 & 0.218 \\
\hline
\end{tabular}

Table(7) indicates that there is statistical significant impact of social media characteristics (Participation, Openness, Conversation, Community, and Connectedness) on Post purchase evaluation through $F$ value $(68.412)$ at $(\alpha \leq 0.05)$. and the value of $R^{2}(0.464)$ indicates that, social media characteristics explained (\%46.4)of the variation in Post purchase evaluation. And The $\mathrm{R}$ value is (\%68.1) that means there is a positive relationship between social media characteristics and Post purchase evaluation.
The results of the partial analysis for this hypothesis shows that the dimension (Participation) achieved the first rank in the contribution of direct impact in the group on Post purchase evaluation where shown through $(\beta)$ value $(0.394)$, and $(\mathrm{T})$ value (8.558), at $(\alpha \leq 0.05)$. While the dimension (Conversation) achieved the second rank in the contribution of direct impact in the group on Post purchase evaluation where shown through $(\beta)$ value $(0.248)$, and $(\mathrm{T})$ value $(4.460)$, at 
$(\alpha \leq 0.05)$. While the dimension (Community) achieved the third rank in the contribution of direct impact in the group on Post purchase evaluation where shown through $(\beta)$ value $(0.109)$, and $(\mathrm{T})$ value $(2.151)$, at $(\alpha \leq 0.05)$. However, the other dimensions did not achieve contribution on the impact in the group on Post purchase evaluation where shown through $(\beta)$ value and $(T)$ value that shown in table $(7)$ at $(\alpha \leq 0.05)$.

According to the previous we reject the null hypothesis and accept the alternative hypothesis Where it was proved that there is significance statistical impact at $(\alpha \leq 0.05)$ of social media characteristics on Post purchase evaluation.

\section{DISCUSSION, CONCLUSION, AND RECOMANDATIONS \\ 6.1 Social Media Characteristics}

The researcher examined the perception of study sample where it consisted of Jordanian Universities Students in Amman about social media Characteristics, additionally, the researcher arrange these Characteristics descending order according to their Means.

The characteristics that exhibits the highest means are openness and connectedness where both of them achieved high importance level where it agrees with [4], which is a clear indicator that Jordanian Universities Students in Amman can access social media networks smoothly and without any barriers; moreover, the students are enabled to interact in social media networks without any obstacles. In addition, Universities Students in Amman usually use the same identity in different social media networks, additionally; they enable to share contents in one social media networks from other social media networks through using links.

On other hand Conversation, Community, and Participation achieved moderate importance level according to the students perceptions, where the reasons are regarding to Conversation, stream of that the students are rarely do engaged in conversation with strange people or they try to help people they don't know in solving their problems regarding the use of social media; moreover, they do not consider the social media as instrument to communicate students feelings and share emotions or use it to develop close relationships with others, are the reasons that cause to achieve moderate importance level to Community, finally, Participation had the lowest share of importance among all characteristics because of that, students do not tend to start or to engage in discussions about products/ services with their friends in social media networks.

\subsection{Customer Purchasing Process}

Social media always forms a rich source of information specially that regarding to product and services, and never once happened we surf our Facebook, Twitter, or any other social media site without seeing a massive amount of advertising for product and services, indeed, from that point we streamed one of the main objective of our study, and after investigating the perception of study sample we found that; the student consider social media an effective instrument to gain different opinions about products or services and searching for products and services information is more easer through social media which is agree with [21]

Nevertheless, all the stages of customer purchasing process achieved a moderate importance level according to the perception of Universities students of Amman, where information search stage got the highest mean, then need recognition, evaluation of alternatives, purchase decision, and post-purchase evaluation .
Where these results were derived from the following reasons;

Firstly, Jordanian Universities Students in Amman do not usually see social media as a stimulator to recognize a need for product/service

Secondly, Jordanian Universities Students in Amman don't consider their friends reviews, talking, or uploading content (pictures, videos) about product/service on social media as a trigger to try or buy these product/service.

Thirdly, considering information in social media more credible than traditional media, it is not one of the beliefs of Universities students of Amman.

Fourthly, final purchase decision of Universities students of Amman often is not impacted by social media and they are not interested with providing a rate or write reviews for other people about product/services in social media after purchase.

The result was proved that there is significance statistical impact of social media characteristics on Need recognition, where social media characteristic can play a significant role in trigger customer unfulfilled need through advertisements or discussions with friends, for example, when Facebook user cliché "like" button or write "comment" in advertisement for product or service all his friends on Facebook will see this "like" or "comment". In addition, YouTube and Twitter can make the same contribution for need recognition stage because they act in the same way which leads to trigger new need for other people, in addition this result in consisting with the results that founded by([26], [20],[25]) .

Moreover, the result was proved that there is significance statistical impact at $(\alpha \leq 0.05)$ of social media characteristics on Information Search, because Social media forms a rich source of information, where customer can ask "friends" or fined the required information in brands pages they "like" in facebook of "follow" in twitter, and it's agree with ( [26], [20], [25]) .

In addition, The result shown that there is significant impact of social media characteristic on Evaluation of alternatives, where social media characteristic enables new customers to discussion with the former or the current customer which enables them to acquire valuable information, that enables them to labile products or services and compare among the alternatives that available to them in order to make the choice that seems more suit to their unfulfilled need, and it agrees with the result founded by ( [26],[20]) .

Also, The result proved that there is significance statistical impact at $(\alpha \leq 0.05)$ of social media characteristics on purchasing decision. Because the results that customer gained from information search and evaluation of alternative stages that relied on opinions, reviews, and recommendations in social media characteristic, and this result agree $\operatorname{with}([26],[20] \mathrm{m}[24])$.

Finally, The result shown that there is significant impact of social media characteristic on Post-Purchase Evaluation, where social media characteristic allows customer to share their own experience and provide reviews and recommendations with peers, and it's the same conclusions of ([26],[24],[19]) .

\subsection{Recommendations}

Social medial became one of the most effective instrument that used by companies in order to achieve their both short 
and long term objects. However, social media is a doubleedged sword, where using this instrument wrangle could lead to damage or even to destroy the organization reputation that requires a massive amount of time, money, and effort to build.

In the light of the study the researcher recommended the following:

1-Companies who use social media should focus on increase conversation with and among customers through being more responsive to customers' queries and trigger customers to establish conversations about their products and services, because the biggest influence of social media is on information search and evaluation alternative stages in customer purchasing process, and these two stages usually determine whether the customer will choice your product or product of your competitors

2- Companies should focus on customer's feedbacks and make it reflect appositive image about the company through being highly committed to their promises especially that regard to after sales services.

3- The researcher highly recommends companies to being super honest in the information that provided about products and services and make that information consisted with the information provided by other customer.

5- Focus on social media advertisements about new products and services and make it reachable to all target customers in order to stimulate their needs

6-We recommend companies to encourage the customer to share the contents that related to their products and services through establish competitions.

7-We recommend companies to encourage their customers to share review and provide feedback about company after purchase.

8-The companies should use social media characteristics to assess the customer purchasing process, as well as focus on the factors existed in social media that can affect the customer purchasing process.

9- Companies should use incentive methods to win customers electronically, such as offering prizes and incentives.

10- Companies should utilize the feature of social sites to improve customer confidence in e-procurement.

\section{REFERENCES}

[1] Yogesh, F. and Yesha ,M. (2014). Effect of Social Media on Purchase Decision, Pacific Business Review International,6 (11), 1-46.

[2] Kaplan ,A. and Haenlein ,M. (2010). Users of the world, unite! The challenges and opportunities of Social Media, Business Horizons, 3(53) 1-10. Available online at www.Sciencedirect.com.

[3] Muniz, A. M., andO'Guinn, T. C. (2001). Brand community. Journal of Consumer Research, 27(4) 122.

[4] Chan, S., Cho, M., and Lee, S. (2013). User Perceptions of Social Media: A Comparative Study of Perceived
Characteristics and User Profiles by Social Media, Online Journal of Communication and Media Technologies,3(4) 1-30.

[5] Mayfield, A.(2008), What is Social Media, E-book Available at: www.icrossing.com.

[6] Meadows-Klue, D. (2007). Falling in love 2.0: Relationship marketing for the Facebook generation. Journal of Direct, Data \& Digital Marketing Practice, 9(4) 245-250

[7] Rowley, J. (2004). Just another channel? Marketing communications in e-business. Marketing Intelligence \& Planning, 22(1), 24-41.

[8] Pilch, C. (2009). Social media marketing and web 2.0: What are they, and how can they help you bring in more business, Business West 4(1) 1-18.

[9] Stafford, L., Kline, S. K., andDimmick, J. (1999). Home e-mail: Relational maintenance and gratification opportunities. Journal of Broadcast and Electronic Media, 43(4) 659-669.

[10] Teixeira, R.A. (1992).The disappearing American voter. The Brookings Institution. USA.

[11] Ha, L., and James, E. L. (1998). Interactivity reexamined: A baseline analysis of early business Web sites. Journal of Broadcasting \& Electronic Media, $42(4), 456-473$.

[12] Familmalek M, Aghighi A, Hamidi K,(2015).Analyzing the Influence of Sales Promotion on Customer Purchasing Behavior, International Journal of Economics \& Management Sciences,4(4),1-6.

[13] Ozer S, (2012).The effect of social media on consumer buying decision process, Master these, National College of Ireland, UK.

[14] Kotler, P., Keller, K.L., Brady, M., Goodman, M. and Hansens, T. (2009), Marketing Management, Pearson Education Limited, London

[15] Jashari,F.(2017). The impact of social media on consumer behavior - Case study Kosovo, Journal of Knowledge Management, 1(5)

[16] Mitchell, V W \&Boustam, P (1994). A Preliminary Investigation into Pre- and Post-Purchase Risk Perception and Reduction, European Journal of Marketing, 28, (1), 56-71

[17] Campbell, M C and Good stein, R C (2001). The Moderating Effect of Perceived Risk on Consumers' Evaluations of Product Incongruity Preference for the Norm, Journal of Consumer Research, 28(7),39-49.

[18] Kardes F.R, Cronley M.L, Cline T.W, (2011). Consumer Behavior, second edition, South-Western. USA.

[19] Westbrook, R A (1987). Product/Consumption-Based Affective Responses and Post-Purchase Processes, Journal of Marketing Research, 24 (8), 258-270.

[20] Gros (2012). The influence of Social Media on consumers during their purchase decision-making process and the implications for marketers. Master Thesis, Dublin business school, Ireland. 
[21] Hoyer, W.D. and MacInnis, D.J. (2010). Consumer behavior. 5th edition. South-Western Cengage Learning. London.

[22] Belch, G.E. and Belch, M.A. (2003). Advertising and promotion: an integrated marketing communications perspective. $6^{\text {th }}$ edition, McGraw-Hill, England.

[23] Brown, D. and Hayes, N. (2008).Influencer marketing: who really influences customers?. First edition, Butterworth-Heinemann, New York.

[24] Sekaran, U, and Bougie, R, (2010). Research Methods for Business: A skill Building Approach, 5th edition, NY: John Wiley \& Sons Inc., New York.
[25] Mangold, W. G., and Faulds, D. J. (2009). Social media: The new hybrid element of the promotion mix. Business Horizons, 52(4), 357-365.

[26] Khatib,F. (2016). The Impact of Social Media Characteristics on Purchase Decision Empirical Study of Saudi Customers in Aseer Region, International Journal of Business and Social Science, 7,(4) 1-10. 